\title{
Development of the automated immunomonitoring system
}

\author{
Ryuji Osawa ${ }^{1 *}$, Sachiko Yoshimura', Shoji Hisada', Koji Yoshida', Tsuyoshi Tojo ${ }^{2}$, Hidenori Kuwata ${ }^{2}$ \\ From Society for Immunotherapy of Cancer 29th Annual Meeting \\ National Harbor, MD, USA. 6-9 November 2014
}

Cancer vaccine which induces cytotoxic T lymphocyte targeting tumor associated antigens is one of major stream in cancer immunotherapy. Many cancer immunotherapy programs are in the clinical development all over the world and also the identification of biomarker for pharmacodynamics and patient selection should be considered.

Enzyme-linked immunospot (ELISPOT) assay is one useful method to detect antigen specific $\mathrm{T}$ cell response as an immunomonitoring. However, the standardization of the ELISPOT assay has not yet been established, and it has strongly been mandatory to detect accurate and objective immune response for clinical development of cancer vaccine. To overcome this problem, we have developed an automated immunomonitoring system, which performs cell culture processes including cell recovery, seeding and detection of the particular cells for ELISPOT assay. This automated cell culture system might be useful to control the quality of assays with cell culture and high-throughput outcomes. In this presentation, we show the concept and the characteristic of the automated immunomonitoring system.

\section{Authors' details}

${ }^{1}$ OncoTherapy Science, Inc., Kawasaki City, Japan. ${ }^{2}$ Panasonic Healthcare Co., Ltd., Minato-ku, Japan.

Published: 6 November 2014

doi:10.1186/2051-1426-2-S3-P153

Cite this article as: Osawa et al:: Development of the automated

immunomonitoring system. Journal for ImmunoTherapy of Cancer 2014

2(Suppl 3):P153.
Submit your next manuscript to BioMed Central and take full advantage of:

- Convenient online submission

- Thorough peer review

- No space constraints or color figure charges

- Immediate publication on acceptance

- Inclusion in PubMed, CAS, Scopus and Google Scholar

- Research which is freely available for redistribution
() Biomed Central

'OncoTherapy Science, Inc., Kawasaki City, Japan

Full list of author information is available at the end of the article

(c) 2014 Osawa et al.; licensee BioMed Central Ltd. This is an Open Access article distributed under the terms of the Creative Commons 